\title{
Efficacy of some Bioagents and Plant Extracts in Controlling TylenchulusSemipenetranson Citrus in Egypt
}

\author{
Samaa. M. Shawky*and Ahlam M. Al-Ghonaimy ** \\ * Nematode Research Department, Plant Pathology Research Institute, Agricultural Research Center, Giza, Egypt \\ ${ }^{* *}$ Plant Protection Department, Nematology Unite- Desert Research Center, Cairo, Egypt
}

\begin{abstract}
This study was conducted to determine the susceptibility of four citrus rootstock; Sour orange (SO), Volkameriana (VOL), Cleopatra mandarin (CM) and Troyer citrange (TC) to citrus nematode; Tylenchulussemipenetrans and control citrus nematodes by using bioagents and plant extracts under both greenhouse and fieldconditions. In addition to determine the citrus yield (cv. Volkameriana) in Egypt.

Data showed that Volkameriana is the most susceptible rootstock; whereas Troyer citrange is the least susceptible rootstock to the citrus nematodes under greenhouse conditions.

Seven treatments (Psudomonasfluorescens, Arthrobotrysoligospora, Trichodermaharzianum, Origanummajorana,Tageteserecta, Eucalyptus globules, at different concentrations, and oxamyl (24\%)) were used to control T. semipenetrans under both greenhouse and fieldconditions on citrus.

The most effective treatment in controlling citrus nematodes; $T$. semipenetrans was Psudomonasfluorescens whereas the least effective was suspension of Eucalyptus globules under both greenhouse and field conditions. Psudomonasfluorescens was more effective in reducing numbers of egg laying females, number of eggs/ egg-mass and number of second stage larvaein the soil, whereas the suspension of Eucalyptus globules was the least effective under both greenhouse and field conditions.

Under greenhouse conditions all treatments led to increase the total fresh weight of shoots and roots of citrus seedlings especially at the highest concentration. The application of treatments achieved high decrease in nematodes population in both roots and soil under both greenhouse and field conditions also, increased the yield of citrus under field conditions.
\end{abstract}

Key words:efficacy, rootstock, citrus nematodes, T. semipenetrans, Psudomonasfluorescens,

Arthrobotrysoligospora, Trichodermaharzianum,

Origanummajorana,Tageteserecta, Eucalyptus globules,oxamyl andcitrus. 


\section{Introduction}

Citrus (Citrus spp.) are considered of the most important horticultural crops in Egypt, due to their economic export value and their local consumption and industries. Also, it is one of the major fruit crops of global importance and cultivated in more than 125 countries. Approximately $68 \%$ of the world's citrus production is consumed as fresh fruits, and about $11 \%$ of total production is used in international trade (Anonymous, 2002). Numerous nematode species are associated with the citrus rhizosphere such as: the citrus nematode,Tylenchulussemipenetrans(Duncan, 1999). In the recent years, the awareness of the nematicides hazards to human and environment has directed the attention towards soil-borne antagonists and the natural plant extracts as an alternative method to chemical control. Biological control and natural plant extracts are gaining an increasing role throughout the world for decreasing nematode population.

Psudomonasfluorescenshas been reported as a biocontrol agent against nematodes (Devi and Upma, 2002; Hamid et al., 2003; Mahapatra and Mohanty, 2003; Raoet al., 2004; Siddiqui\&Shaukat, 2005 and Shawky, et al., 2010) as well asArthrobotrysoligosporahas been mentioned by (Bandyopadhyayet al., 2001; Duponnoiset al., 2001; Singh et al., 2001; Khan et al., 2002;El Gendy\&Shawky; 2006and Aliet al., 2012). Trichodermharzianum act through different mechanisms including mycoparasitism, also through production of antibiotic substances (Sharon et al., 2001; Faruk et al., 2002; Shawky and Abd El- Moneim, 2005; Sahebani \&Hadavi, 2008 and Shawky, et al., 2010).

The impact of aqueous plant extracts on plant parasitic nematodes has been reported by several authors. Plant extracts of Tageteserecta has nematicidal effect on root-knot nematode (Kimpinskiet al., 2000; El-Hamawiet al., 2004; Verma, 2006; Khalil \&Shawky, 2008 and Ali etal., 2012). Also, plant extracts of Origanummajaranacontaining some substances reduce the nematode populations (Saravanapriyaet al 2004; Shawkyet al., 2010 and Ali et al., 2012).Eucalyptus; Eucalyptus globuleshas nematicidal effect on nematode population according to (Sabiraet al., 2000;Shaukatet al., 2003 and 2006 Ali et al., 2012).

The aim of this work determine the suitability of four citrus rootstocks to citrus nematode and evaluation of different bioagents and plant extracts treatments to control citrus nematodes; Tylenchulussemipenetrans on citrus under both greenhouse and fieldconditions in Egypt.

\section{Material and Methods}

The experiments were conducted under greenhouse and field conditions. The field experiment was conducted in a naturally infested field with 
Tylenchulussemipenetrans on citrus trees in a private vineyard situated at CairoAlexandria desert road $\left(78^{\text {th }}\right.$ kilometer).

\section{Greenhouse experiments}

1. Host susceptibility of some citrus rootstocks to the citrus nematode; T. semipenetrans

Two year's old healthy seedlings belonging to the most widespread commercial rootstocks in Egypt were obtained from Citrus Research Dept., ARC, Giza. Rootstocks used were: Sour orange (Citrus aurantum L.), Volkameriana (C. volkameriana Ten et Pas), Cleopatra mandarin (C. reshniL.) and Troyer citrange (C. sinensis $x P$. trifoliate L.).These rootstocks were examined for their relative susceptibility to the infection of citrus nematode; T. semipenetrans. Five seedlings of each rootstock were put in clay pots each pot (one seedling/pot) filled with sandy loamy soil ( $18 \%$ clay, $10 \%$ silt and $72 \%$ sand) steam sterilized soil.

Each pot was inoculated with 3000 newly hatched larvae of $T$. semipenetrans around the roots one week after planting. All rootstocks received the same agricultural treatments. Each rootstock replicated five times as well as five seedlings for each rootstock was kept without inoculation to serve as a check. All pots were arranged in completely randomized design, and kept under greenhouse conditions at about $25-28^{\circ} \mathrm{C}$.

After 120 days, all plants were carefully uprooted and fresh root and shoot systems were weighted. Nematode populations in soil (number of juveniles/ $250 \mathrm{~g}$. soil) were determined according to (Franklin \&Goodey, 1957) Roots were stained by acid fuchsin in acetic acid according to (Byrd et al.1983), and examined for egg laying females/1g.root. Eggs /egg-mass of $T$. semipenetrans were extracted by using sodium hypochoride $(\mathrm{NaOCl})$ method as described by (Husssey and Baker, 1973).

2. Efficacy of some concentration of some bioagents and plant extracts in controlling citrus nematode; $T$. semipenetrans

In this study seven different treatments were used:

\section{Bioagents micro-organisms}
1. Psudomonasfluorescens.
2. Trichodermaharzianum.

3.Arbascularmycorrhizae.

\section{Plant aqueous extracts}

4. Marjoram; Origanummajorana. 5. Marigold;Tageteserecta.

6. Eucalyptus, Eucalyptus globules. 


\section{Nematicide}

\section{Oxamyl (24\% EC).}

The concentrations of Psudomonasfluorescens $\left(1 \times 10^{5}, 1 \times 10^{8}, 5 \times 10^{8}\right.$ cells $) /$ pot, Arthrobotrysoligospora and Trichodermaharzianum were $\left(1 \times 10^{5}, 1 \times 10^{8}, 5 \times 10^{8} \mathrm{cfu}\right) /$ pot. While,fresh leaves of three plants were marjoram; Origanummajorana, marigold;Tageteserectaand Eucalyptus, Eucalyptus globules. The plants were prepared by using three concentrations; (C1) $10 \mathrm{~g} . / 100 \mathrm{ml}$. sterilized distilled water, (C2)15g./100ml. sterilized distilled water and (C3)20g./100 ml. sterilized distilled water/ pot against $T$. semipenetrans.

The Psudomonasfluorescenswas taken from Microbiology Department, Soils, Water and Environment Research Institute, Agriculture Research Center. Arthrobotrysoligospora and Trichodermaharzianum were taken from Plant Pathology Department, Faculty of Agriculture, Cairo University and oxamyl was used in the recommended concentration (5L/feddan).

The rate of application for each plant aqueous extracts was $(100 \mathrm{ml} . /$ seedling). Also, oxamyl (vydat; 24\% EC) asnematicide at the recommended concentration ( $24 \% \mathrm{EC})$ at the rate of application $(5 \mathrm{~L} / 600 \mathrm{~L}$ water /fed).

Two year's old healthy citrus seedlings, Volkameriana rootstock were transplanted individually in clay pots each pot containing sandy loamy soil $(18 \%$ clay, $10 \%$ silt and $72 \%$ sand) steam sterilized soil. Each pot was inoculated with 3000 newly hatched larvae of $T$. semipenetrans around the roots. All treatments received the same agricultural treatment. Each treatment replicated five times. All pots were arranged in completely randomized design, and kept under greenhouse conditions at about $25-28^{\circ} \mathrm{C}$. The citrus seedlings were treated with each mentioned concentration/ pot of the treatments suspension of (Psudomonasfluorescens, ArthrobotrysoligosporaandTrichodermaharzianum),

(Origanummajorana,Tageteserectaand Eucalyptus globules) and oxamyl (24\% EC). Also, five citrus seedlings were treated with newly hatched larvae of $T$. semipenetrans alone as check.

After 120 days, all plants were carefully uprooted and fresh root and shoot systems were weighted. Nematode populations in soil (number of juveniles/250g. soil) were determined according to (Franklin \&Goodey, 1957). Roots were stained by acid fuchsin in acetic acid according to (Byrd et al.,1983) and examined for number of egg laying females/1g.root. Eggs/egg-mass of $T$. semipenetrans were extracted by using sodium hypochoride $(\mathrm{NaOCl})$ method as described byHusssey and Baker (1973).

\section{Efficacy of number of application of some bioagents and plant extracts in controlling $T$. semipenetrans on citrus $\mathrm{cv}$. Volkameriana}

Citrus seedlings (Volkameriana rootstock), Two year's old healthy seedlings 
were planted in clay pots each containing steam sterilized sandy loamy soil $(18 \%$ clay, $10 \%$ silt and $72 \%$ sand) soil. The treatments were designed in five replicates (one seedling for each pot).

This experiment was conducted to determine the effect of some bioagents and plants extracts in controlling $T$. semipenetrans by using the highest concentration of the suspension of bioagents at concentration $\left(5 \times 10^{8}\right.$ cfu\& $5 \times 10^{8}$ cells) and the plant extracts at concentration $(20 \mathrm{~g} . / 100 \mathrm{ml}$. sterilized distilled water) under greenhouse conditions at about $\left(25-28^{\circ} \mathrm{C}\right)$. Each pot was inoculated with 3000 newly hatched larvae of $T$. semipenetrans around the roots. All treatments received the same agricultural treatment. Each treatment replicated five times.

After 120 days, all plants were carefully uprooted and fresh root and shoot systems were weighted. Nematode populations in soil (number of juveniles/ $250 \mathrm{~g}$. soil) were determined according to (Franklin \&Goodey, 1957) Roots were stained by acid fuchsin in acetic acid according to (Byrd et al., 1983), and examined for egg laying females $/ \mathrm{g}$ root. Eggs legg-mass of $T$. semipenetrans were extracted by using sodium hypochoride $(\mathrm{NaOCl})$ method as described byHusssey and Baker (1973).

\section{Field experiments}

Efficacy of some bioagents and plants extracts in controlling citrus nematode; T. semipenetranson citrus

This experiment was conducted in naturally infested sandy soil to determine the efficacy of some bioagents and plant extracts treatments to control $T$. semipenetrans under field conditions at the high concentration $(20 \mathrm{~g} . / 100 \mathrm{ml})$ for plant extracts and at the high concentration $\left(5 \times 10^{8}\right.$ cfu\& $5 \times 10^{8}$ cells $)$ for the bioagents. Oxamyl at the rate of $5 \mathrm{~L} /$ Feddan was used as recommended concentration. All treatments were replicated three times (every replicate was ten trees of citrus).

Every month, nematode populations in both soil and root including number of second stage juveniles $/ 250 \mathrm{~g}$. and egg laying females and eggs/egg-mass/gm. root were determined after treatments to the harvesting time during the growing season according to (Franklin \&Goodey, 1957). Roots were stained by acid fuchsin in acetic acid according to (Byrd et al., 1983) and examined for number of egg laying females $/ 1 \mathrm{~g}$. Eggs legg-mass of $T$. semipenetrans were extracted by using sodium hypochoride $(\mathrm{NaOCl})$ method as described by (Husssey and Baker, 1973). At the end of the experiment the fruit yield of citrus were determined.

\section{Statistical analysis procedure}

All obtained data were subjected to analysis of variance (ANOVA) Gomez and Gomez (1984) and means were compared by using L.S.D. at $5 \%$ level of significance. 


\section{Results and Discussion}

\section{Greenhouse experiments}

1. Host susceptibility of some citrus rootstocks to the citrus nematode; T. semipenetrans

Data in table (1) indicate that citrus is a good host for the citrus nematode, T.semipenetransin all rootstocks.Volkameriana rootstock was the most susceptible rootstock to the citrus nematode in comparing to other tested rootstocks, while Troyer citrange rootstock exhibited some resistance to the citrus nematode. The nematode population in $250 \mathrm{~g}$ soil and in root (egg laying females and number of eggs/ egg mass) were significantly higher on Volkameriana rootstock than those on the other tested rootstocks $(P<0.05)$. Cleopatra-mandarin and Sour-orangeranked statistically in the intermediate category in nematode population in both soil and roots.

Table (1): Reproduction of citrus nematode, T. semipenetrans on some citrus rootstocks.

\begin{tabular}{lccc}
\hline \multirow{2}{*}{ Rootstocks } & \multicolumn{3}{c}{ Nematode population } \\
\cline { 2 - 4 } & $\begin{array}{c}\text { No. of } \\
\text { nematodes in } \\
\text { soil/250 g. }\end{array}$ & $\begin{array}{c}\text { No. of egg laying } \\
\text { females }\end{array}$ & $\begin{array}{c}\text { No. of } \\
\text { eggs legg-mass }\end{array}$ \\
\hline Cleopatramandarin & $4280 \mathrm{~B}$ & $51 \mathrm{~B}$ & $315 \mathrm{~B}$ \\
Sourorange & $1180 \mathrm{C}$ & $29 \mathrm{C}$ & $219 \mathrm{C}$ \\
Troyer citrange & $580 \mathrm{D}$ & $18 \mathrm{D}$ & $169 \mathrm{D}$ \\
Volkameriana & $5600 \mathrm{~A}$ & $72 \mathrm{~A}$ & $354 \mathrm{~A}$ \\
L. S. D. at $\mathbf{0 . 0 5 \%}$ & 87.9 & 16.4 & 55.8 \\
\hline
\end{tabular}

Numbers followed by the same letter (s) within a column are not significantly different $(P=0.05)$ according to Duncan's new multiple- range test.

Fig. (1) showed the reduction of total fresh weights (shoot and root) of the tested infected cultivars with $T$. semipenetrans compared with non-infected cultivar plants. Volkameriana rootstock showed the highest reduction in total fresh weights (shoot and root), while Troyer citrangerootstock showed the lowest reduction in total fresh weights (shoot and root). 


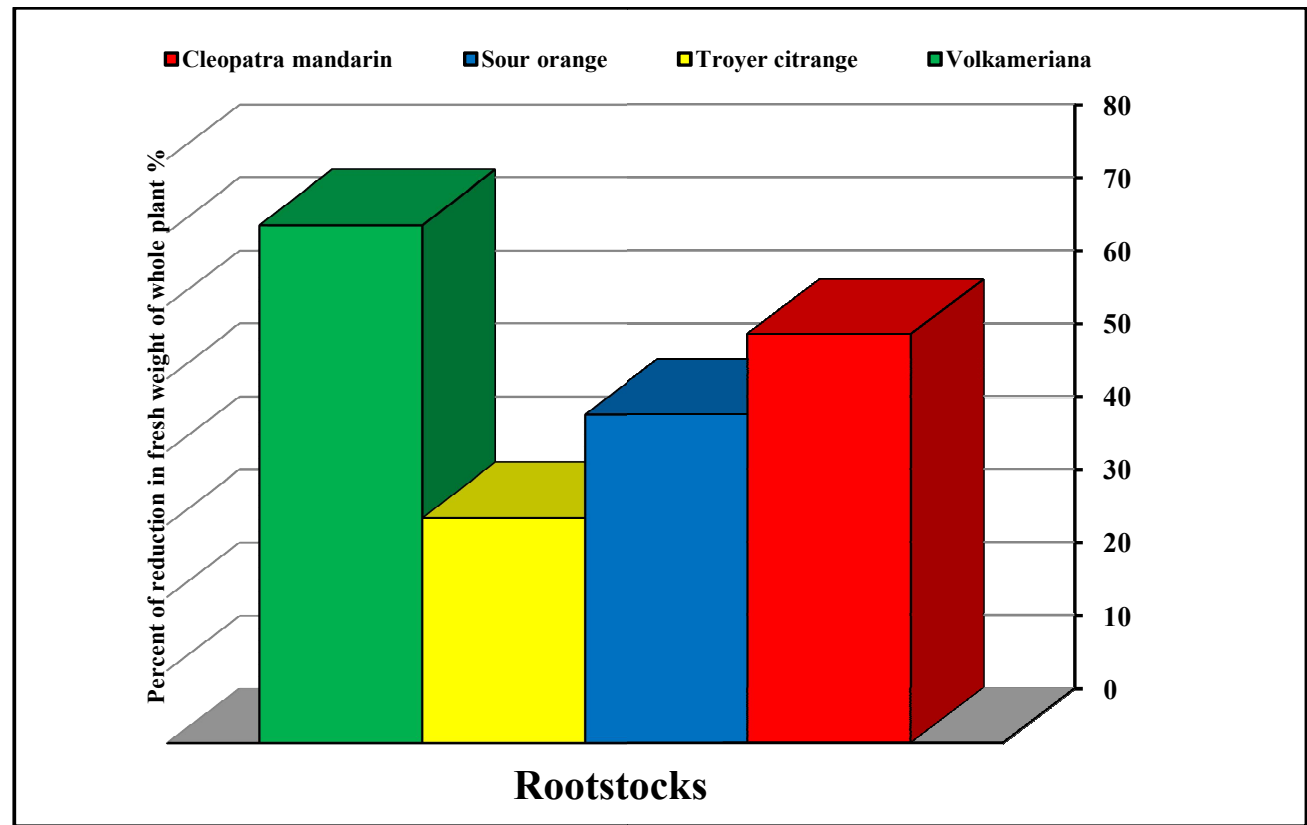

Fig. (1): Reduction\% of total fresh weights of some citrus rootstocks infected with T. semipenetrans compared with healthy rootstocks.

\section{Efficacy of some concentration of some bioagents and plant extracts in controlling $T$. semipenetranson citrus}

\section{A. The effect on nematode population of citrus nematode; T. semipenetrans}

Data in table (2) showed that all tested bioagents and plant extracts treatments were effective in controlling citrus nematode; T. semipenetrans under greenhouse conditions. Psudomonasfluorescens treatments were the most effective treatment than the other treatments whereas the least effective treatment was the Eucalyptus globules. Also, data showed that positive correlation between efficacy of the treatments and concentrations.

Data in table (2) revealed that by usingPsudomonasfluorescensat $\left(5 \times 10^{8}\right.$ cells) achieved the highest decrease in both soil/ $250 \mathrm{~g}$ and root (egg laying females, number of eggs/ egg-mass) comparing with the other treatments. Trichodermaharzianum, Arthrobotrysoligospora, Origanummajorana andTageteserectaoccupied the second rank in reducing the nematode populations, whereas, Eucalyptus globules at the rate of $10 \mathrm{~g}$. $/ 100 \mathrm{ml}$. resulted in the lowest number of nematode population in both soil and roots. 
Table (2): Effect of concentration of some bioagents and plant extracts on nematode population of $T$. semipenetrans on citrus (Volkameriana rootstock).

\begin{tabular}{|c|c|c|c|c|}
\hline \multirow[b]{3}{*}{ Treatments } & \multirow{3}{*}{ Concentration / pot } & \multicolumn{3}{|c|}{ Nematode population } \\
\hline & & \multirow{2}{*}{$\begin{array}{c}\text { No. of } \\
\text { nematodes in } \\
\text { soil } / 250 \mathrm{~g} \text {. }\end{array}$} & \multicolumn{2}{|c|}{ On $1 \mathrm{~g}$. root } \\
\hline & & & $\begin{array}{l}\text { No. of egg laying } \\
\text { females }\end{array}$ & $\begin{array}{c}\text { No. of } \\
\text { eggs legg-mass }\end{array}$ \\
\hline \multirow{3}{*}{$\begin{array}{c}\text { Psudomonasfl } \\
\text { uorescens }\end{array}$} & $1 \times 10^{5}$ cells & 530 & 35 & 157 \\
\hline & $1 \times 10^{8}$ cells & 330 & 28 & 145 \\
\hline & $5 \times 10^{8}$ cells & 260 & 23 & 131 \\
\hline \multirow{3}{*}{$\begin{array}{c}\text { Arthrobotrysol } \\
\text { igospora }\end{array}$} & $1 \times 10^{5} \mathrm{cfu}$ & 720 & 39 & 185 \\
\hline & $1 \times 10^{8} \mathrm{cfu}$ & 680 & 33 & 178 \\
\hline & $5 \times 10^{8} \mathrm{cfu}$ & 520 & 29 & 169 \\
\hline \multirow{3}{*}{$\begin{array}{l}\text { Trichodermah } \\
\text { arzianum }\end{array}$} & $1 \times 10^{5} \mathrm{cfu}$ & 590 & 37 & 162 \\
\hline & $1 \times 10^{8} \mathrm{cfu}$ & 490 & 31 & 155 \\
\hline & $5 \times 10^{8} \mathrm{cfu}$ & 410 & 25 & 142 \\
\hline \multirow{3}{*}{$\begin{array}{l}\text { Eucalyptus } \\
\text { globules }\end{array}$} & $10 \mathrm{~g} . / 100 \mathrm{ml}$. water & 1940 & 47 & 231 \\
\hline & $15 \mathrm{~g} . / 100 \mathrm{ml}$. water & 1820 & 71 & 225 \\
\hline & $20 \mathrm{~g} . / 100 \mathrm{ml}$. water & 1680 & 62 & 219 \\
\hline \multirow{3}{*}{$\begin{array}{c}\text { Origanummajo } \\
\text { rana }\end{array}$} & $10 \mathrm{~g} . / 100 \mathrm{ml}$. water & 840 & 48 & 225 \\
\hline & $15 \mathrm{~g} . / 100 \mathrm{ml}$. water & 760 & 41 & 201 \\
\hline & 20 g. $/ 100$ ml. water & 680 & 36 & 188 \\
\hline \multirow{3}{*}{ Tageteserecta } & $10 \mathrm{~g} . / 100 \mathrm{ml}$. water & 1120 & 52 & 224 \\
\hline & $15 \mathrm{~g} . / 100 \mathrm{ml}$. water & 980 & 54 & 219 \\
\hline & $20 \mathrm{~g} . / 100 \mathrm{ml}$. water & 740 & 43 & 205 \\
\hline \multicolumn{2}{|c|}{ Oxamyl (24\% EC) } & 180 & 11 & 109 \\
\hline \multicolumn{2}{|c|}{ Check control (nematodes only) } & 5160 & 89 & 356 \\
\hline \multicolumn{2}{|l|}{ L. S. D. at $0.05 \%$} & 36.9 & 2.1 & 9.3 \\
\hline
\end{tabular}

Numbers followed by the same letter $(s)$ within a column are not significantly different $(P=0.05)$ according to Duncan's new multiple- range test.

\section{B. The effect on total fresh weights (shoot and root)}

All the treatments provoked the total fresh weight of treated seedlings compared with the infected seedlings with;T. semipenetrans. The results in fig. (2) revealed different response in total fresh weight of shoots and roots by using different concentrations. Themaximum increasing $\%$ at the highest concentrations $\left(5 \times 10^{8} \mathrm{cfu}\right.$ in the bioagents and $20 \mathrm{~g}$. $/ 100 \mathrm{ml}$. water of the plant extracts. Also, 
Psudomonasfluorescens increased the total fresh weight with $(83.3 \%)$ while; Eucalyptus globules increased the total fresh weight with (32.6\%). Arthrobotrysoligospora, Trichodermaharzianum, Origanummajorana and Tageteserecta ranked in the intermediate position.

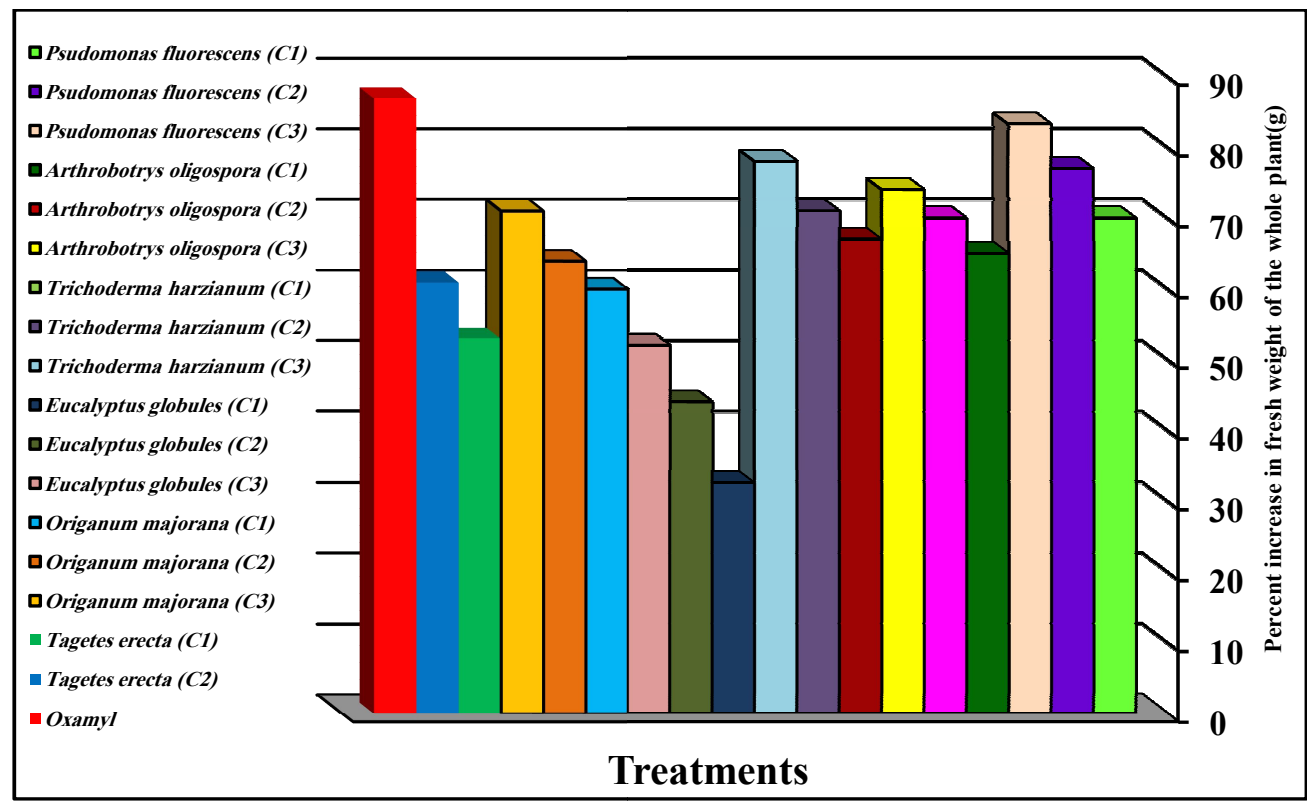

Fig. (2): Efficacy of some bioagents and plant extracts at different concentrations on increasing \% of total fresh weights of citrus seedlings infected with T. semipenetrans.

\section{Field experiments}

\section{Efficacy of some bioagents and plant extracts in controlling $T$. semipenetrans}

\section{A. The effect on nematode population; T. semipenetrans}

This trial was carried out under field conditions on citrus trees in a private vineyard situated at Cairo- Alexandria desert road $\left(78^{\text {th }}\right.$ kilometer). The trial was conducted in sandy soil area whereas the nematode infestation is somewhat homogenized on Volkameriana trees. Thenematode population were counted throughout the experimental period and documented in table (3). Total nematode population in both soil and root samples revealed the suppressive effect of all materials on the nematode counts. In general, the nematode counts decreased gradually in both soil and root of the treated trees.

Results showed an increase in the efficacy percentages of the treatments and caused a decrease in total nematode population ranging between (36-61\%) after one month. Then, remarkable suppression in nematode counts obtained after two months or more expect after the fourth month the total nematode population in 
both soil and root samples increased. At the end of experiment all the treatments gave satisfactory reduction in the nematode counts.

\begin{tabular}{|c|c|c|c|c|c|c|c|c|c|c|c|}
\hline \multirow{4}{*}{$\frac{1}{\frac{1}{8}}$} & Trestrments & Conc/ tree & $\begin{array}{l}\text { Inital } \\
\text { Total } \\
\text { populstion in } \\
\text { soilland roots * }\end{array}$ & $\begin{array}{l}\text { After one m } \\
\text { Total } \\
\text { population in } \\
\text { sol and roots" }\end{array}$ & Effoscy & \multicolumn{2}{|c|}{ After two months } & \multicolumn{2}{|c|}{$\begin{array}{l}\text { After three months } \\
\text { Totel }\end{array}$} & \multicolumn{2}{|c|}{$\begin{array}{l}\text { After four months } \\
\text { Tots } \\
\text { populion in } \\
\text { soil and root. Effecy }\end{array}$} \\
\hline & Psuchmonos fuavescens & $5 \times 10^{x}$ cells & 2620 & 1290 & (s8) & 1220 & $(\boxplus)$ & 980 & $(\pi)$ & 1990 & (73) \\
\hline & Arthrobotys aligapora & $5 \times 10^{x} \mathrm{ctu}$ & 2540 & 1450 & $(92)$ & 1320 & (ब) & 1160 & $(\pi)$ & 1280 & $(>0)$ \\
\hline & Michoderma hazionum & $5 \times 10^{x} \mathrm{cfu}$ & 2980 & 1390 & (25) & 1290 & (ळ) & 1050 & ( $\pi)$ & 1240 & (72) \\
\hline \multirow{3}{*}{$\frac{\mathrm{E}}{\mathrm{E}}$} & Excalyptus gobules & $20 \mathrm{~g} / 100 \mathrm{~mL}$. water & 2690 & 1990 & (36) & 1740 & $(\mathbf{s})$ & 1540 & (64) & 1700 & (52] \\
\hline & anganummajorano & $20 \mathrm{~g} / 100 \mathrm{~mL}$. water & 2540 & 1700 & (49) & 1490 & $(\boldsymbol{\alpha})$ & 1270 & $(\pi)$ & 1440 & (68) \\
\hline & Tagetes erecto & $20 \mathrm{~g} / 100 \mathrm{~mL}$. water & 2960 & 1820 & (40) & 1970 & $(\mathbf{8})$ & 1390 & (घ) & 1520 & (59) \\
\hline \multicolumn{2}{|c|}{ Oxerty [ (2466 EC) } & & 2600 & 1200 & (51) & 1100 & $(71)$ & 890 & (T)] & 1060 & (76) \\
\hline \multicolumn{2}{|c|}{ Cheok [nerretose only] } & & 2890 & 3390 & - & 4200 & - & 4900 & - & 4340 & - \\
\hline \multicolumn{2}{|c|}{ LS. D. at $0.05 \%$} & & 23.9 & 457 & & $s 9.1$ & & 775 & & 57.1 & \\
\hline
\end{tabular}

$-250 \mathrm{~g} 80 \mathrm{lll}+1 \mathrm{~g}$ roots

Percentage of nematode redudion fom soll f\% eftcacy acoor ing to Handerson \& Tilton fo mula, (Anonymous, 1981)

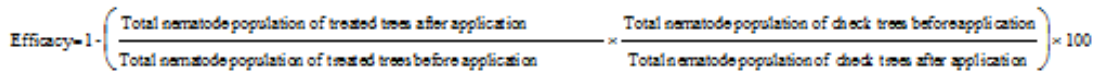


Data in table (3) reveled that by using Psudomonasfluorescens the highest decrease in the total number of nematodes in both soil and root samples was achieved in comparing with the other treatments. Arthrobotrysoligospora,Trichodermaharzianum and origanummajorana andTageteserecta occupied an intermediate position in reducing the number of total of nematodes while Eucalyptus globules showed the lowest efficacy in reducing total number of nematodes in both soil and root samples.

\section{B.The effect on yield fruit weights}

Data in fig. (3) illustrated the effect of different bioagents and plant extracts on fruit weights of citrus after treatments under field conditions. All the treatments showed remarkable increasing $\%$ in fruit weights. The treatment Psudomonasfluorescenshad the highest effect in the increasing of fruit weights $(54.1 \%)$. While, the treatment Eucalyptus globules had the lowest effect in the increasing of fruit weights $(22.2 \%)$.

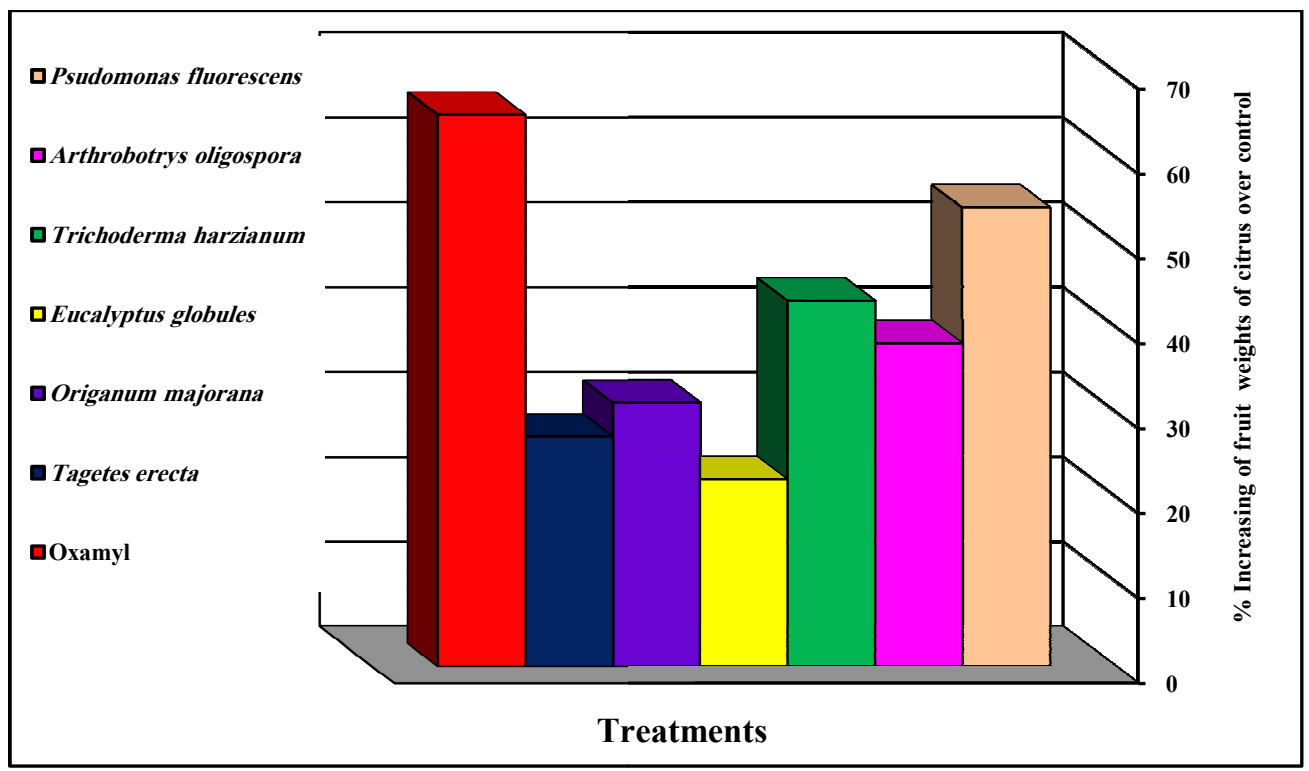

Fig. (3): Efficacy of some bioagents and plant extracts on increasing \% of fruit weights of citrus trees infected with $T$. semipenetrans under field conditions.

These results may due to that

Psudomonasfluorescens,Arthrobotrysoligosporaand Trichodermaharzianum has produce various toxin metabolites and different enzymes that improve photolytic activity of the antagonist and control of nematodes (Duponnoiset al., 2001; Singh et al., 2001; Devi and Upma, 2002; Khan et al., 2002; Hamid et al., 2003; Mahapatra and Mohanty, 2003; Raoet al., 2004; Siddiqui\&Shaukat, 2005; EI Gendy\&Shawky, 2006; Shawkyet al., 2010and Aliet al., 2012). 
Psudomonasfluorescenshas been reported as a biocontrol agent against nematodes (Upma, 2002; Hamid et al., 2003; Mahapatra and Mohanty, 2003; Raoetal., 2004; Siddiqui\&Shaukat, 2005 and Shawkyet al., 2010) as well asArthrobotrysoligosporahas been mentioned by (Bandyopadhyayet al., 2001; Duponnoiset al., 2001; Singh et al., 2001; Khan et al., 2002; El Gendy\&Shawky, 2006and Ali et al., 2012). T. harzianum acts against nematode through different mechanisms including mycoparasitism, also through production of antibiotic substances (Banhamoud\& Chet 1993). Trichodermaharzianum acts through production of destructive enzymes i.e., chitenase(Bolar et al., 2000). Trichoderma spp. can produce various toxin metabolites and different enzymes that improve photolytic activity of the antagonist against nematodes. (Sharon et al., 2001;Faruk et al., 2002;Siddiqui and Shawkat, 2004;ShawkyandAbd El- Moneim, 2005;Sahebani andHadavi, 2008 andAbd El- Moneimet al.,2010).

Plant aqueous extracts of O. majarana,T. erecta and Eucalyptus globules decreased the build up of nematodes (El-Hamawiet al., 2004; Khalil \&Shawky 2008Shawkyet al., 2010and Ali et al., 2012). The active ingredients of $O$. majaranacontaining active substances i.e. thimol, alcavacrol, alorzamanik acid. Also it contains pilot oil: major components, hydrates alsabinin, alcarvakrwol, inalol, flavonyat, alcaviien acid,alagoesarniek acid and triturbines(Saravanapriyaet al., 2004).T. erecta contains lemonene,linalool,tagetone,ocimene,d-phellaudrene,linalyl acetate,n-nonyl aldehyde,1,8-cineole (Ploeg 1999). (El-Hamawiet al., 2004 and Verma,2006) cited that the nematicidal compound (alpha-tertheinyl) is only released by active, living marigold roots.Also, Eucalyptus globules leaves contain volatile oil contain: (cencol, pinene, phellendrene, terpincol citronellal, piperitone, astringents and bitter princills). These compounds have nematicidal effect on nematode population according to (Sabiraet al., 2000;Shaukatetal., 2003; Shawky, et al., 2010and Ali et al., 2012). All these compounds exhibited substantial activity against species of pathogens such as: nematodes. Using the application of nematicides to control citrus nematode in citrus was reported by (McKenry, 1994).

\section{Conclusion}

From the foregoing results, it can be concluded that Volkameriana rootstock was the most susceptible cultivar; whereas Troyer citrange rootstock was the least susceptible cultivar to the citrus nematodes under greenhouse conditions. The most effective treatments in controlling $T$. semipenetrans were $P$. fluorescens (at $5 \times 10^{8}$ ) whereas the least effective was Eucalyptus globules under both greenhouse and field conditions. All the treatments improved fruit yield of citrus under field conditions.

\section{References}


Abd El- MoneimMaisa L., ShawkySamaa M. and SolimanManal M. (2010). Efficacy of some bioagents, chitosan compounds and organic peels extract in controlling Meloidogynehapla on strawberry in Egypt. Minuifiya J. Agric. Res. 35 (3):843-861.

Ali, Mervat A.; Samaa M. Shawkyand GhadaS.Shaker(2012). Comparative efficacy of some bioagents, plant oil and plant aqueous extracts in controlling Meloidogyne incognita on growth and yield of grape vines.Annal Agric. Sci., Ain Shams Univ.,Cairo, 57(1)110-222.

Anonymous (1981). Manual for field trail in plant protection. Edited and published By Werner Puntener, Agricultural Divion, Ciba-Geigy Li-mited, Basle, Switzerland, $205 \mathrm{pp}$.

Anonymous (2002). Citrus Fruit Fresh and Processed Annual Statistics. Food and Agriculture Organization of the United Nations, Rome, Italy.

Bandyopadhyay, P.; Kumar, D.; Singh,V.K. and Singh,K.P. (2001). Eco-friendly management of root-knot nematode of tomato by Arthrobotrysoligosporaand Dactylariabrochopaga. Indian-Journal-ofNematology. 2001; 31(2): 153-156.

Benhamoud, W. and I. Chet (1993).Hyphal interaction between TrichodermaHarzianum and Rhizoctoniasolaniultra structure and Gold cytochemistry of mycoparasitic process Phytopathology, 83: 1026-1071.

Bolar, J.P.; J.L. Norelli; K.W.Wong; C.K. Hayes; Q.E. Harman and H.S. Aldwinckle (2000).Expression of endochitinase from Trichodermnharziianumintransgenic apple increase resistance to apple scab and reduces vigour.Phytopathology, 90: 72-77.

Byrd, D.W.; T. Kirkpatrick and K.R. Barker.(1983). An improved technique for cleaning and staining plant tissues for detection of nematodes. J. Nematol., 15(1):142-143.

Devi, L.S. and Upma, D. (2002). Effect of Pseudomonas fluorescens on root-knot nematode (Meloidogyne incognita) of okra plant. Indian-Journal-ofNematology; 32(2): 215-216.

Duncan, L.W. (1999) Nematode diseases of citrus. In: Timmer, L.W. and Duncan, L.W. (eds) Citrus Health Management. APS Press, St Paul, Minnesota, pp. 136-148.

Duponnois, R.; Chotte, J.L.; Sall, S. and Cadet, P. (2001). The effects of organic amendments on the interactions between a nematophagous fungus 
Arthrobotrysoligospora and the root-knot nematode Meloidogynemayaguensis parasitizing tomato plants. Biology-and-Fertilityof-Soils. 34(1): 1-6.

El Gendy, Rafaat, S.S and Shawky, Samaa M. (2006). Efficacy of some natural plants and bioagents to minimize the population of root-knot nematode; Melidogyne incognita in superior seedless vineyards and its reflection on vine growth and yield. $1^{\text {st }}$. International Egyptian-Jordanian Conference, pp. 281-293.

El-Hamawi M. H., Youssef M. M. A. and Zawam H. S.(2004). Management of Meloidogyne incognita, the root-knot nematode, on soybean as affected by marigold and Aambrosia maritime (damsisa) plants. J. of Pest Science, 77(2): 95-98.

Faruk, M.I., M.L. Rahman and M.A. Bari. (2002).Mangement of root-knot nematodes of tomato using Trichodermaharzianum and organic soil amendment. Bangladesh Journal of Plant Pathology, 18: 33-37.

Franklin, M.T. and Goodey, J.B. (1957). A cotton-blue lactophenol technique for mounting plant parasitic nematodes. J. Helminthological abstracts; 23:175178.

Gomez K. W. and Gomez A. A. (1984). Statistical procedures for agricultural Research $2^{\text {nd }}$ Ed. John Wiley and Sons inc., New York680P.

Hamid, M.; Siddiqui, I.A. and Shaukat, S.S. (2003). Improvement of Pseudomonas fluorescens CHAO biocontrol activity against root-knot nematode by the addition of ammonium molybdate. Letters-in-AppliedMicrobiology; 36(4): 239-244.

Khalil A. E. and ShawkySamaa M. (2008). Combination of the nematophagous fungus Paecilomyceslilacinus and aqueous leaf extracts in controlling Meloidogynejavanica infecting potato. Egypt. J. Agronematol., 6 (2): 185 196.

Khan, M.R.; Kounsar, K. and Hamid, A. (2002). Effect of certain rhizobacteria and antagonistic fungi on root-nodulation and root-knot nematode disease of green gram. Nematologia-Mediterranea; 30(1): 85-89.

Kimpinski J., Arsenault W. J., Gallant C. E. and Sanderson J. B. (2000).The effect of marigolds (Tagetesspp.) and other cover crops on Pratylenchuspenetrans and on following potato crops.J. Nematol., 32 (4): 531-536.

Mahapatra, S.N. and Mohanty, K.C. (2003). Management of root-knot nematode in 
brinjal using Pseudomonas fluorescens and its compatibility with carbofuran.

ProceedingsofNationalSymposiumonBiodiversityandManagement of NematodesinCroppin Systems for Sustainable Agriculture,Jaipur; 135-137.

McKenry, M.V. (1994). Nematodes of olive. In 'Olive Production Manual' p.97-9. Ed. Ferguson, L., Sibbett, G.S., and Martin, G.C. University of California Division of Agriculture and Natural Resources, Oakland. Pub. 3353.

Ploeg A. T. (1999). Greenhouse studies on the effect of marigolds (Tagetes spp.) on fourMeloidogyne species. J. Nematol., 31(1):62-69.

Rao, M.S.; Dhananjay, N. and Shylaja, M. (2004). Bio-intensive management of root-knot nematodes on bell pepper using Pochoniachlamydosporia and Pseudomonas fluorescens. Nematologia-Mediterranea; 32(2): 159-163.

Sabira, B.; Aneela, W.; Siddiqui, B.S. and Fatima, Qamar (2000).Nematicidal constituents of the aerial parts of Lantana camara. Journal-of-NaturalProducts; 63(6): 765-767.

Sahebani, N. and N. Hadavi. (2008). Biological control of the root-knot nematode Meloidogynejavanica by Trichodermaharzianum. Journal of Soil Biology \& Biochemistry, 40: 2016-2020.

Saravanapriya, B., M. Sivakumar, G. Rajendran and S. Kuttalam. (2004). Effect of different plant products on the hatching of Meloidogyne incognita eggs. Indian Journal of Nematology, 34:690-697.

Sharon, E., E.M. Bar, I. Cheti, A.E. Herrera, O. Kleifeled and Y. Splegel. (2001). Biological control of the root-knot nematode Meloidogynejavanica by Trichodermaharzianum. Phytopathology, 91: 687-693.

Shaukat, S.S.; Siddiqui, I.A.; Ali, N.I.; Ali, S.A. and Khan, G.H. (2003).Nematicidal and allelopathic responses of Lantana camara root extract. Phytopathologia-Mediterranea; 42(1): 71-78.

Shawky, Samaa M. and Abd El- Moneim, Maisa L. (2005). Non chemical control of root - knot nematode, Meloidogyne incognita on grape vines.Minufiya J. Agric. Res., 30(6): 1685- 1708.

Shawky, Samaa M., A.E. Khalil and Manal M. Soliman (2010). Non chemical control of root-knot nematode; Meloidogynejavanicaon peanut in Egypt.Zagazig J. Agric. Res., 37 (1): 185-206. 
Siddiqui, I.A. and Shaukat, S.S. (2005). Phenylacetic acid-producing Rhizoctoniasolani represses the biosynthesis of nematicidal compounds in vitro and influences biocontrol of Meloidogyneincognita in tomato by Pseudomonas fluorescens strain CHAO and its GM derivatives. Journal-ofApplied-Microbiology. 2005; 98(1): 43-55.

Singh, K.P.; Dharmendra, K.; Bandhyopadhyay, P. and Singh, V.K. (2001). Predation and performance of two predacious fungi for control of root-knot nematode of brinjal. Journal-of-Mycopathological-Research. 2001; 39(2): 95-100.

Verma K. K. (2006). Management of root-knot nematode (Meloidogynejavanica) in fieldpea (Pisumsativum) by intercropping with marigold (Tageteserecta). J. Annals of Agri. Bio. Research, 11 (2): 121-122. 


\section{الملخص العربي}

\section{كفاءة بعض الكائنات الحية والمستخلصات النباتية في مكافحة}

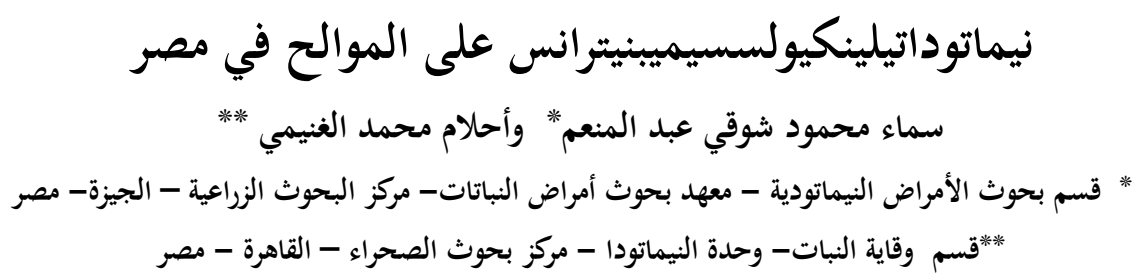

أجريت هذه الدراسة لاختبار حساسيةأربعة أصول منالموالح(البرتقال الحامضي وفولكا مريانا

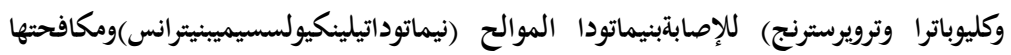
تحت ظروف الصوبة والحقل. وكذلك تقدير محصول ثمار الموالح (أصل فولكاماريانا) بعد العدابل

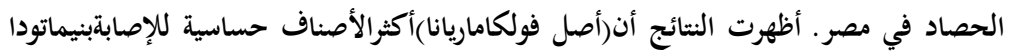

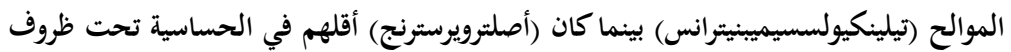
الصوبة.

تم اختبار سبعة معاملات (بكتريا البسيدومونسفلوروسنس وفطر الأرثروبتريتسأوليجوسبوراوفطر

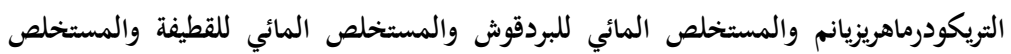

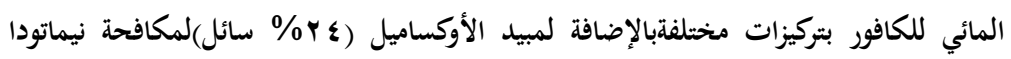
الموالح (تيلينكيولسسيميبنيترانس) تحت ظروف كلا من الصوبة والحقل على الموالح.

كانت أكثرالمعاملات فعاليةفي مكافحةنيماتودا الموالح بكتريا البسيدومونسفلوروسنس بينما

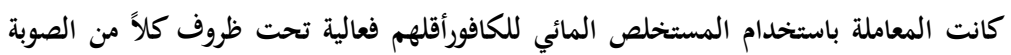

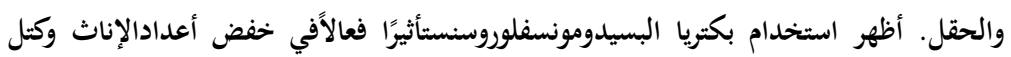

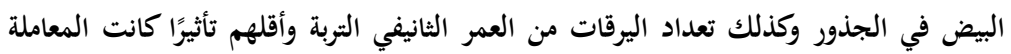
باستخدام المستخلص المائي للكافور تحت ظروف كلاً من اليروات من الصوبة والحقل.

أدى استخدام جميع المعاملات إلى زيادة في الوزن الخضري والجذري لشتلات الموالح

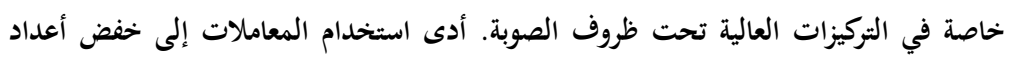

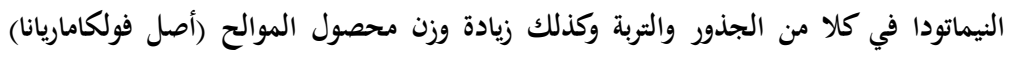
تحت ظروف الحقل. 